Western University

Scholarship@Western

Aboriginal Policy Research Consortium International (APRCi)

2008

Warrki Jarrinjaku 'working together everyone and listening': growing together as leaders for Aboriginal children in remote central Australia

Kathryn Priest

Sharijin King

Irene Nangala

Wendy Nungurrayi Brown

Marilyn Nangala

Follow this and additional works at: https://ir.lib.uwo.ca/aprci

Part of the Educational Leadership Commons

Citation of this paper:

Priest, Kathryn; King, Sharijin; Nangala, Irene; Brown, Wendy Nungurrayi; and Nangala, Marilyn, "Warrki Jarrinjaku 'working together everyone and listening': growing together as leaders for Aboriginal children in remote central Australia" (2008). Aboriginal Policy Research Consortium International (APRCi). 315.

https://ir.lib.uwo.ca/aprci/315 
This article was downloaded by: [University of Western Ontario]

On: 16 December 2012, At: 08:00

Publisher: Routledge

Informa Ltd Registered in England and Wales Registered Number: 1072954 Registered

office: Mortimer House, 37-41 Mortimer Street, London W1T 3J H, UK

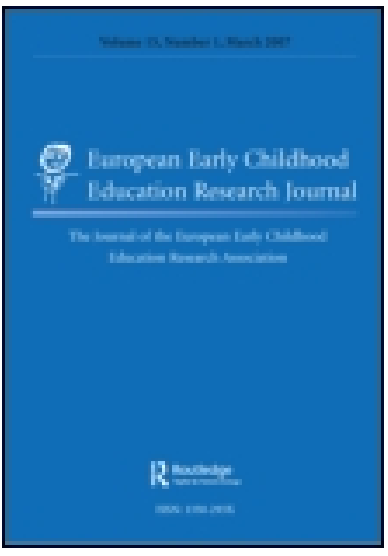

\section{European Early Childhood Education Research J ournal}

Publication details, including instructions for authors and subscription information:

http:// www. tandfonline.com/loi/ recr20

\section{Warrki J arrinjaku 'working together everyone and listening': growing together as leaders for Aboriginal children in remote central Australia}

Kathryn Priest ${ }^{a}$, Sharijn King ${ }^{b}$, Irene Nangala ${ }^{c}$, Wendy Nungurrayi Brown ${ }^{d} \&$ Marilyn Nangala ${ }^{e}$

a Australian Government Department of Families, Housing Community Services and Indigenous Affairs (FaHCSIA), Australia

${ }^{b}$ Waltja Tjutangku Palyapayi Aboriginal Organisation, Alice Springs, Northern Territory, Australia

${ }^{\mathrm{C}}$ Senior Anangu (Aboriginal) woman from Walungurru (Kintore), Northern Territory, Australia

d Senior Yapa (Aboriginal), Yuendumu, Northern Territory, Australia

e Senior Anangu (Aboriginal) woman from Mt Leibig, Northern Territory, Australia

Version of record first published: 20 Aug 2009.

To cite this article: Kathryn Priest, Sharijn King, Irene Nangala, Wendy Nungurrayi Brown \& Marilyn Nangala (2008): Warrki J arrinjaku 'working together everyone and listening': growing together as leaders for Aboriginal children in remote central Australia, European Early Childhood Education Research J ournal, 16:1, 117-130

To link to this article: http:// dx.doi.org/ 10.1080/ 13502930801897186

\section{PLEASE SCROLL DOWN FOR ARTICLE}

Full terms and conditions of use: http://www.tandfonline.com/page/terms-andconditions

This article may be used for research, teaching, and private study purposes. Any substantial or systematic reproduction, redistribution, reselling, loan, sub-licensing, systematic supply, or distribution in any form to anyone is expressly forbidden. 
The publisher does not give any warranty express or implied or make any representation that the contents will be complete or accurate or up to date. The accuracy of any instructions, formulae, and drug doses should be independently verified with primary sources. The publisher shall not be liable for any loss, actions, claims, proceedings, demand, or costs or damages whatsoever or howsoever caused arising directly or indirectly in connection with or arising out of the use of this material. 


\title{
Warrki Jarrinjaku 'working together everyone and listening': growing together as leaders for Aboriginal children in remote central Australia
}

\author{
Kathryn Priest $^{\mathrm{a} *}$, Sharijn King ${ }^{\mathrm{b}}$, Irene Nangala ${ }^{\mathrm{c}}$, Wendy Nungurrayi Brown ${ }^{\mathrm{d}}$ and Marilyn \\ Nangala $^{\mathrm{e}}$ \\ ${ }^{a}$ Australian Government Department of Families, Housing Community Services and Indigenous Affairs \\ (FaHCSIA), Australia; ${ }^{b}$ Waltja Tjutangku Palyapayi Aboriginal Organisation, Alice Springs,, Northern \\ Territory, Australia; ' Senior Anangu (Aboriginal) woman from Walungurru (Kintore), Northern Territory, \\ Australia; ${ }^{d}$ Senior Yapa (Aboriginal), Yuendumu, Northern Territory, Australia; ${ }^{e}$ Senior Anangu \\ (Aboriginal) woman from Mt Leibig, Northern Territory, Australia
}

\begin{abstract}
This article outlines an early childhood leadership model that senior Anangu and Yapa (Aboriginal) women, living semi-traditional lifestyles in the remote desert regions of central Australia, have identified as a positive and important way forward for their children, families, governments and related professionals. The initiative - Warrki Jarrinjaku Jintangkamanu Purananjaku (Warrki Jarrinjaku), Warlpiri for 'working together everyone and listening' - is a collaboration between senior Anangu and Yapa women from the central desert, Waltja Tjutangku Palyapayi Aboriginal Organisation (Waltja) and the Australian Government Department of Families, Housing Community Services and Indigenous Affairs (FaHCSIA). It is also known as the Aboriginal Child Rearing Strategy (ACRS). This article also discusses some of the key findings from the Warrki Jarrinjaku ACRS project and explores its emerging influence in early childhood practice within Australia and internationally.
\end{abstract}

RÉSUMÉ: Cet article présente un modèle de direction de la petite enfance que des femmes Aborigènes Anangu et Yapa, vivant de façon semi-traditionnelle dans les régions désertiques d'Australie centrale, considèrent comme positif et important pour leurs enfants, leurs familles, leurs gouvernements et leurs professionnels. L'initiative - Warrki Jarrinjaku Jintangkamanu Purananjaku, (Warrki Jarrinjaku) Warlpiri pour 'travailler ensemble et s'écouter'- résulte d'une collaboration entre des femmes Anangu et Yapa du désert central, l'organisation aborigène Waltja Tjutangku Palyapayi (Waltja) et le ministère des Familles, des Services à la Communauté et des Affaires Indigènes du gouvernement australien (FaHCSIA). Elle est également connue sous le nom de Stratégie Aborigène d'Accueil de l'Enfant (ACRS).

ZUSAMMENFASSUNG: Die indigenen australischen Völker der Anangu und Yapa leben auf halb-traditionelle Weise in abgelegenen Wüstengebieten Zentralaustraliens. Dieser Artikel umreißt ein kooperatives Führungsmodell in der Frühpädagogik, das von rangälteren Frauen dieser Völker als positiv und wichtig für ihre Kinder, Familien, Regierungsstellen und Fachkräfte identifiziert wurde. Warrki Jarrinjaku Jintangkamanu Purananjaku, (Warrki Jarrinjaku) Warlpiri bedeutet 'alle arbeiten zusammen und hören zu' und steht für eine gemeinsame Initiative zwischen rangälteren Anangu- und Yapa-Frauen, der Waltja Tjutangku Palyapayi Aboriginal Organisation (Waltja) und dem Australischen Ministerium für Familien, Gemeinwesenarbeit und Indigene Angelegenheiten (FaHCSIA). Die Initiative ist auch als Indigene Erziehungs-Strategie (Aboriginal Child Rearing Strategy, ARCS) bekannt. Der Artikel diskutiert einige der zentralen Ergebnisse des Warrki Jarrinjaku ACRS Projekts und erörtert dessen wachsenden Einfluss auf die Australische und internationale Frühpädagogische Praxis.

\footnotetext{
*Corresponding author. Email: kathryn.priest@fahcsia.gov.au; katiemay@chariot.net.au
} 
RESUMEN: Este documento resalta un modelo de liderazgo en la temprana edad que mujeres mayores Anangu y Yapa (Aborígenes) que viven estilos de vida semi-tradicionales en las remotas regiones del desierto de Australia Central han identificado como una positiva e importante manera de aprendizaje para sus niños, familias, gobiernos y profesionales relacionados. La iniciativa - Warrki Jarrinjaku Jintangkamanu Purananjaku, (Warrki Jarrinjaku) Warlpiri para 'trabajar juntos y escuchar todos' - es una colaboración entre las mujeres Annangu y Yapa del desierto central, la Organización Aborigen Waltja Tjutangku Palyapayi (Waltja) y el Departamento Gubernamental de Familias, Servicios Comunitarios y Asuntos Indígenas Australianos (FaCSIA). Es también conocido como la Estrategia de Crianza de Niños Aborígenes (ACRS). Este documento también discute algunos de los descubrimientos claves del proyecto ACRS Warrki Jarrinjaku y explora su emergente influencia en la práctica de la enseñanza en la temprana edad tanto en Australia como internacionalmente.

Keywords: Aboriginal community leadership; working together; listening

All images in this article, including Figure 1, have been reproduced with permission from Waltja Tjutangku Palyapayi Aboriginal Organisation, Alice Springs, Northern Territory, Australia.

\section{Explanation of terms}

Understanding terms and how they are being used is necessary in gaining some understanding of the project and the culture and the deeply held values of the Aboriginal peoples.

ACRS - Aboriginal Child Rearing Strategy - a series of projects exploring Aboriginal child-rearing practices in the desert regions of central Australia. The project is also known as Warrki Jarrinjaku Jintangkamanu Purananjaku.

Anangu - The people, as distinct from animals, land, plants (Pitjantjatjara, Pintupi, Luritja language groups).

Both ways - Both ways usually refers to the environment in a service, such as a school on a remote Aboriginal community. A learning environment will be 'both ways' where there is a blend of mainstream and Indigenous cultural knowledge being taught. An ideal 'both ways' environment places equal value and respect on quality practices from both Kardiya (non-Aboriginal) and Yapa (Aboriginal) cultures.

Dreaming - See Jukurrpa below.

Family mapping - Family mapping is an innovative research technique that is being explored in Warrki Jarrinjaku ACRS. Not wanting to rely on recording their stories in English, Aboriginal

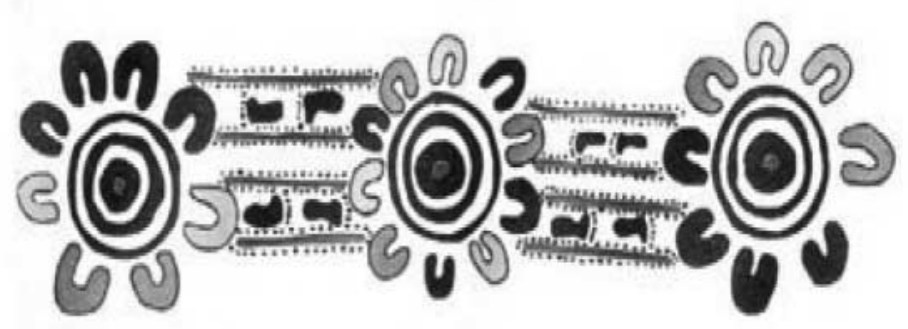

Figure 1. The emblem of the Aboriginal Organisation Waltja Tjutangku Palyapayi. 


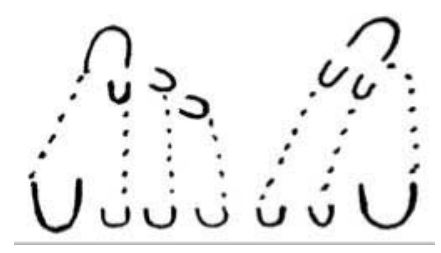

Figure 2. Family mapping. Children learning about Tjukurpa by watching old women dancing.

women are experimenting with using their own 'written language', 'family mapping', to describe their child-rearing practices. These are the drawings and designs seen in the Western Desert paintings. Figure 2 is an example of this.

Intercultural - Russell Taylor, the former Chief Executive Officer of the Australian Institute of Aboriginal and Torres Strait Islander Studies Canberra, Australia states that it is necessary for the cultural knowledge and experiences of Indigenous people to be 'respected and given currency' in the same way that non-Indigenous knowledge is (Taylor 2003, 45). To achieve this aim, he argues that it is essential to create and work within an 'intercultural space'. Intercultural is defined as:

the 'meeting of two distinct cultures' through processes and interactions which retain the distinctive integrity and difference of both cultures and which may involve a blending of elements of both cultures but never the domination of one over another ... (Taylor 2003, 45)

Jukurrpa - The Dreaming, the Law (Warlpiri language). Jukurrpa is the period in the remote past when ancestral beings created the social, moral and physical universe. Jukurrpa is also in the present and has ongoing reality through the continuity of the practices that constitute Anangu and Yapa law and culture.

Kardiya - Non-Aboriginal person (Warlpiri).

Kulini - A simple English translation of Kulini (Pintupi language) is to 'listen' and 'understand'. But it is much more. Kulini means that a person grows in understanding and acknowledges their relatedness to everything in their environment, and they are able to subdue their own will in order to sustain relatedness.

Languages - See Table 1 for Aboriginal language groups involved in Warrki Jarrinjaku ACRS.

Mainstream - The greater number or majority. It is used as a general term to identify the most usual or widespread culture in a country - for example, the culture that is prevalent in the national government, health and education systems.

Table 1. Aboriginal language groups involved in Warrki Jarrinjaku ACRS.

\begin{tabular}{ll}
\hline Alyawarri & Ngaanyatjarra \\
Anbara & Ngaatjatjarra \\
Anmatyerre & Pintupi \\
Arrente & Pitjantjatjara \\
Kija & Warlpiri \\
Kukatja & Yankunytjatjara \\
Luritja & \\
\hline
\end{tabular}


Tjukurpa - Pitjantjatjara and Luritja languages - meaning the same as Jukurrpa.

Tjukurrpa - Pintupi language - the same meaning as Jukurrpa.

Traditional - 'Traditional people' generally refers to Indigenous people who have English as a second or third language, and who usually live in the most remote and isolated regions of Australia.

Walytja, Waltja - Family, extended family, all family (Pitjantjatjara, Pintupi, Luritja languages).

Waltja - Family in Luritja and Pintupi languages. Also used as an abbreviation for the Aboriginal organisation Waltja Tjutangku Palyapayi.

Waltja Tjutangku - Luritja for 'Doing good work for families'. The Palyapayi name of an Aboriginal organisation based in Alice Springs, Northern Territory (NT). Principal service provider of the ACRS.

Warrki Jarrinjaku - 'Working together' in Warlpiri, pronounced wah key jarr in jarkoo. Abbreviation for Warrki Jarrinjaku Jintangkamanu Purananjaku (Warlpiri for 'Working together everyone and listening'), also known as the Aboriginal Child Rearing Strategy (ACRS).

Yapa - The people, as distinct from animals, land, plants (Warlpiri language).

\section{Introduction}

Wendy Nungarrayi Brown, Senior Yapa (Aboriginal) woman and co-author of this article, expressed the Warrki Jarrinjaku (working together) vision using Yapa and Anangu written language, as shown in Figure 3.

In translating the meaning into English, Wendy explained:

We need to work together as one, and to follow - supporting one another. This is important ... Kardiya ('white fella') and Yapa (Aboriginal) working together and supporting each other. (Wendy Nungarrayi Brown, personal commentary, 2006)

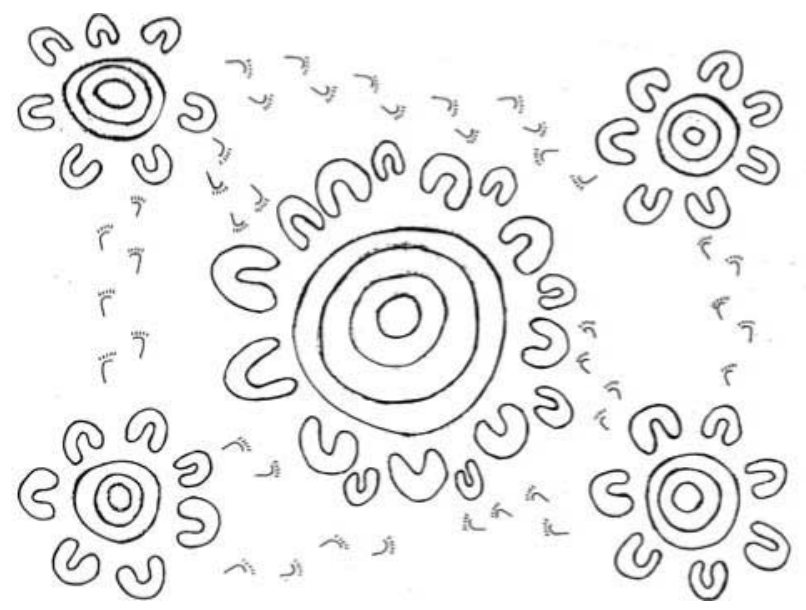

Figure 3. Everyone working together, listening, following and supporting one another. 
The U shapes in Figure 3 represent people - Anangu, Yapa (Aboriginal) and Kardiya (nonAboriginal people) - and the circles show the places where people work and have meetings. The large circle is Canberra, the capital city of Australia and home of the Federal Government, and the four smaller circles are the services and various government departments. The 'feet' link everything and everyone into one entity.

This articler outlines an early childhood leadership model that senior Anangu and Yapa (Aboriginal) women, living semi-traditional lifestyles in the remote desert regions of central Australia, have identified as a positive and important way forward for their children, families, governments and related professionals. The initiative Warrki Jarrinjaku Jintangkamanu Purananjaku (Warrki Jarrinjaku), Warlpiri for 'working together everyone and listening', is a collaboration between senior Annangu and Yapa women from the central desert, Waltja Tjutangku Palyapayi Aboriginal Organisation (Waltja) and the Australian Government Department of Families, Housing, Community Services and Indigenous Affairs (FaHCSIA). It is also known as the Aboriginal Child Rearing Strategy (ACRS). Figure 4 provides images of the area in central Australia. The area where the Warrki Jarrinjaku first started is approximately the size of the United Kingdom.

The Warrki Jarrinjaku ACRS partnership and leadership model is important because Anangu and Yapa (Aboriginal) cultural knowledge is officially recognised as being equal to 'mainstream' knowledge. Senior Ansangu and Yapa women are recording their traditional child-rearing and parenting practices with the aim of strengthening their cultures and improving the well-being, health and educational outcomes of their children.

Warrki Jarrinjaku ACRS recognises that there is a 'gap' in the mainstream knowledge base and this creates an environment where genuine collaboration and shared leadership can occur. Everyone involved is both a teacher and a learner - a leader and a follower. The leadership, power and responsibility are shared. Knowledge builds over time through a process of deep listening and respect - 'everyone working together as one' (Wendy Nungarrayi Brown, personal commentary). For people to work together as 'one', trusted relationships need to be established over a period of time. As Sharijin King explained:

Nothing can be achieved until there is a relationship. If there is no relationship then it won't work.

Relationship is the key. (Sharijn King, Waltja manager, personal commentary 2006)

This article discusses some of the key findings from the Warrki Jarrinjaku ACRS project and explores its emerging influence in early childhood practice within Australia and internationally. It has been written in English, but for senior Annangu and Yapa (Aboriginal) women living in remote communities in central Australia, English is a third or fourth language. The Anangu and Yapa co-authors have translated their knowledge into English, and while every attempt has been made to ensure the integrity of the meaning is maintained, many concepts that are discussed can be conceptually challenging and difficult to define within a western cultural framework. Where possible the women's written language is used; for examples, see Figures 1, 2, 3, 5, 6 and 7. The authors of this article have been working closely together for eight years.

\section{The Australian context}

All the rules for living come from Jukurrpa [Dreaming, the Law]. All the rules for bringing up little kids come from Jukurrpa. It is the main thing. So little kids can learn all the rules, like ceremony and marriage. (Wendy Nungarrayi Brown, personal commentary, 2006)

Aboriginal Elders living in the remote desert regions of central Australia are deeply concerned about the health and well-being of their children. Their communities have endured massive changes in recent years, and in many instances the crisis of colonisation has weakened their 

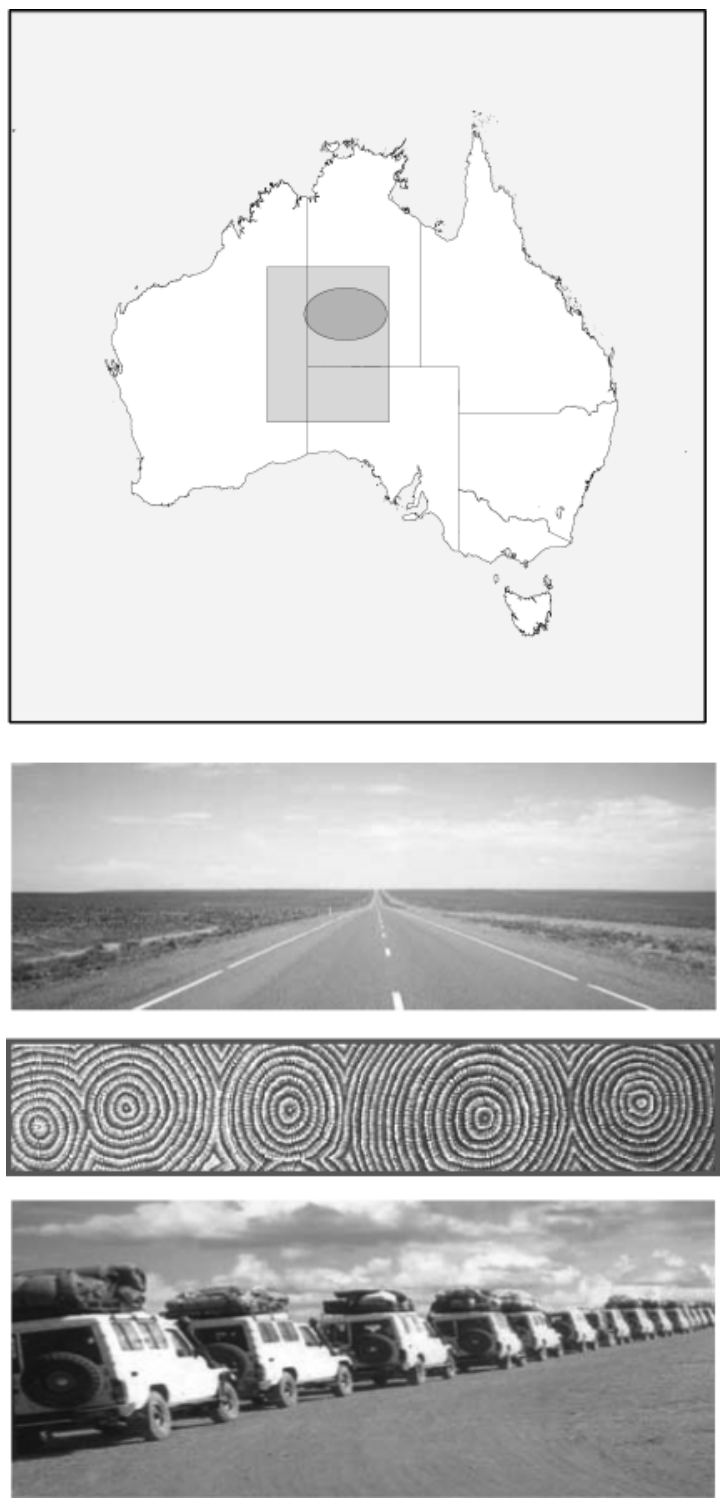

Figure 4. Waltja Tjutangku Palyapayi region in central Australia. The approximate area of central Australia covered by the Aboriginal organisation Waltja Tjutangku Palyapayi. In the online version the dark orange circle is the area where the Warrki Jarrinjaku work first started. This area is approximately the size of the United Kingdom.

families and brought on self-destructive behaviours such as petrol sniffing, violence and alcohol misuse. European settlement in this remote region of Australia did not start in earnest until the 1930s, and in some areas contact is as recent as the early 1970s (Warrki Jarrinjaku ACRS Project Team 2002).

Over the past 30 to 80 years the imposition of mainstream culture and services has failed to deliver the acceptable standards of health and well-being it promised. As with many Indigenous peoples around the globe, Anangu and Yapa children and their families continue to suffer as a result of European settlement. The reasons why the hardship and trauma continues are complex. 
However, in recent times there has been a growing recognition of the need to have a 'both ways' approach to service design and delivery (Warrki Jarrinjaku ACRS Project Team 2002). An ideal 'both ways' environment places equal value and respect on quality practices from both Kardiya (non-Aboriginal) and Annangu and Yapa (Aboriginal) cultures. And while some progress has been made in creating 'both ways' environments in Australia, a lot more needs to be done to ensure Anangu and Yapa cultural knowledge is truly recognised as being as valuable as 'mainstream' knowledge.

For many years formal early childhood services have been dominated by mainstream culture. The desire to achieve the improvement of standards of health and education from a mainstream perspective has inhibited serious interest and investigation into Anangu and Yapa (Aboriginal) child rearing. The emphasis has instead been on the imposition of western practices within a broadly paternalistic framework, assuming the superiority of mainstream views. The Warrki Jarrinjaku ACRS project challenges these assumptions. Table 2 shows the key differences between the principles underlying conventional practice and Warrki Jarrinjaku in central Australia.

Russell Taylor, the former head of the Australian Institute of Aboriginal and Torres Strait Islander Studies Canberra, provided an important description of the type of space that needs to be created for different cultures to work together. Taylor (2003) uses the term 'intercultural' and defines this as:

Table 2. Conventional practice compared to the Warrki Jarrinjaku leadership model. Note: Anangu is used to represent both Annangu and Yapa.

\section{Conventional practice}

Mainstream knowledge is believed to be superior to Anangu culture in its ability to deal with the health and well-being crisis in Anangu communities.

It is assumed that Anangu are deficient in a number of areas. The aim is to 'fix the problem' by addressing Anangu deficiencies.

Key features of conventional practice include:

- service models are designed by non-Anangu;

- service delivery is heavily reliant on nonAnangu;

- the service co-ordinator is non-Anangu;

- non-Anangu are paid a full-time wage, Annangu are on Community Development Employment Program (CDEP);

- it is believed that services cannot operate without non-Annangu staff;

- the service may be described as being 'both ways'; however, in reality is it is dominated by mainstream culture and values;

- Annangu often avoid working in the service;

- non-Anangu usually hold the most powerful positions and make many decisions on behalf of Anangu.

The government-service provider relationship:

- the primary relationship is with non-Anangu;

- non-Anangu staff speak on behalf of Annangu;

\section{Warrki Jarrinjaku leadership model}

Anangu cultural knowledge is formally recognised as being of equal value to mainstream knowledge. The limitations of mainstream knowledge, in relation to its ability to 'fix the crisis' for Anangu, are recognised.

Senior Anangu are treated as experts in their field. The aim is to build on Anangu strengths and expertise.

Key features of Warrki Jarrinjaku include:

- service models designed by Anangu in genuine partnership with professional non-Annangu who facilitate the process (see Warrki Jarrinjaku principles and practices);

- service delivery relies heavily on Anangu;

- the coordinator is Anangu;

- Anangu and non-Añangu are paid a wage;

- non-Anangu staff perform a specific function in the service - they are not the 'boss';

- the program cannot function without Anangu;

- the aim is to equally value and respect quality practices from both mainstream and Anangu culture;

- Anangu specifically ask to work in the service;

- Añangu have greater choice, opportunity and selfreliance.

The government-service provider relationship:

- the primary relationship is with Anangu;

- Anangu speak for themselves; 
Table 2. (Continued).

\section{Conventional practice}

- 'gate keeping' by non-Añangu staff;

- non-Anangu staff focus on the difficulties they encounter providing services to Anangu.

Performance is measured by:

the experiences of non-Anangu staff;

- reports provided by non-Anangu staff;

- the outputs

The training is primarily 'one-way': the focus is on teaching Anangu;

- most of the training is imposed;

- Aangu often choose not to attend the training provided.

The steering committee is dominated by nonAnangu professionals and government representatives who:

- have access to all the critical knowledge associated with the service being developed;

- make the decisions and then inform Anangu about what has been decided. The process may involve asking Anangu if they agree with the decision.

\section{Warrki Jarrinjaku leadership model}

- open and transparent communication between Anangu, the service provider and the government is promoted;

- government and non-government personnel concentrate on providing quality information to Anangu.

Performance is measured by:

- the experiences of Anangu;

- reports provided by Anangu;

- the outcomes for Aangu

The training model is 'two-way':

- Anangu cultural knowledge is formally recognised as being of equal value to mainstream knowledge;

- Anangu are the teachers;

- Annangu want to undertake training;

- Annangu specifically ask to attend training.

The steering committee is made up solely of Anangu. A separate group is formed with professional people and government representatives. The aim is to:

- ensure Anangu have access to quality information and advice to enable them to make informed decisions;

- facilitate the decisions made by Anangu.

the 'meeting of two distinct cultures' through processes and interactions which retain the distinctive integrity and difference of both cultures and which may involve a blending of elements of both cultures but never the domination of one over another ... (Taylor 2003, 45)

\section{Warrki Jarrinjaku Jintangkamanu Purananjaku}

To achieve a balanced 'both ways' approach, senior Anangu and Yapa women have begun recording their child-rearing and parenting practices. A key feature of this work is that the senior women are exploring an innovative research technique known as 'family mapping' with support from staff from the Aboriginal organisation Waltja Tjutangku Palyapayi (Waltja Tjutangku Palyapayi Aboriginal Organisation 2001). Not wanting to rely on recording their stories in English, Anangu and Yapa women experiment with using their own 'written language', family mapping, to describe their child-rearing practices. Significantly, family mapping was used to develop a shared language between the project partners and to encourage genuine intercultural communication. Figure 5 provides an example of family mapping with a design showing four old women teaching young children about Tjukurpa while they all sit around the campfire.

Again, not wanting to rely on English as the shared language within the group, senior Anangu and Yapa women use family mapping to develop a language that can be shared with their project partners. The women use Anangu and Yapa languages to communicate and explain their ideas and share knowledge. For example, in Figure 6 senior women translated Figure 3 of 


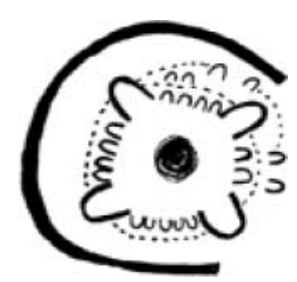

Figure 5. Family mapping. Four old women teaching young children about Tjukurpa while they all sit around the campfire.

this article into a hierarchical structure similar to that used in a 'mainstream' cultural framework. Using a combination of Anangu, Yapa and English languages, the women described their vision, and a way forward, to improve the health and well-being of their families and children Warrki Jarrinjaku Jintangkamanu Purananjaku, Warlpiri for 'everyone working together and listening'.

\section{Warrki Jarrinjaku Jintangkamanu Purananjaku}

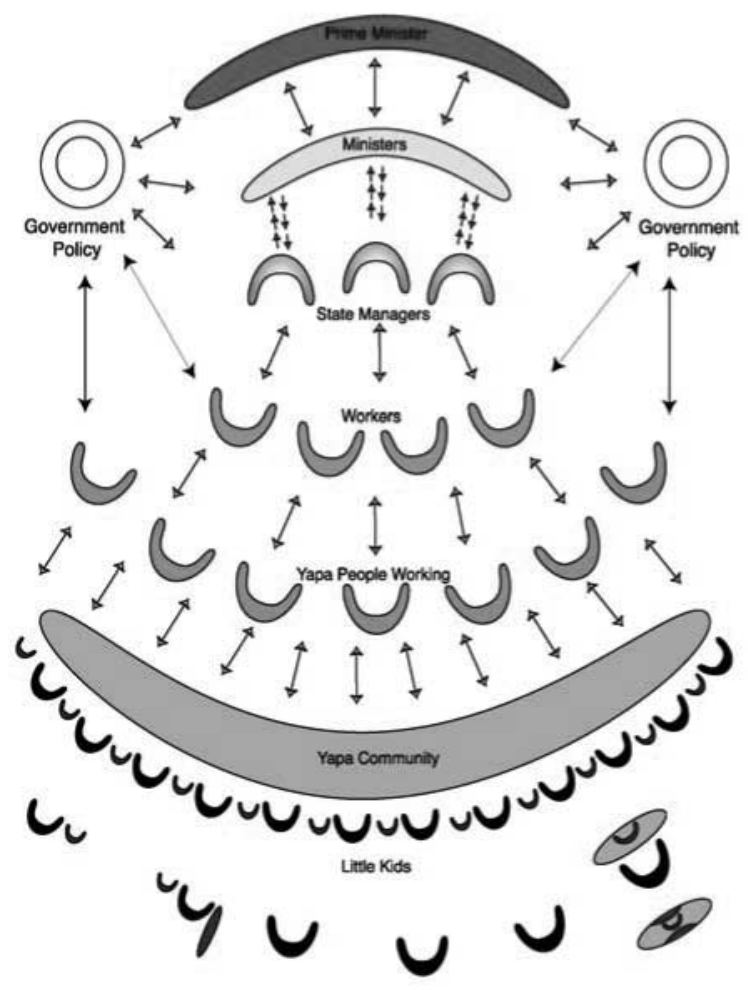

Figure 6. Creating a shared language. This is translated into a hierarchical structure. By using a combination of Anangu, Yapa and English languages, senior Annangu and Yapa women create a 'shared language'. The ultimate meaning remains the same - Warrki Jarrinjaku Jintangkamanu Purananjaku. 


\section{'Growing up' children: the four key principles}

The shared leadership style that is promoted by the senior Anangu and Yapa women in the Warrki Jarrinjaku ACRS project is reflected in their cultures' child-rearing principles and practices. In Anangu and Yapa child rearing, great emphasis is placed on the child developing correct relationships with everything in the environment. Traditional Anangu and Yapa culture is orientated towards the needs of the whole community rather than the individual. The whole community, physical and non-physical environment must be strong for individual children and families to be strong. Anangu and Yapa child rearing, parenting and leadership are motivated and driven by group accomplishment, common goals and shared vision.

In a report produced as part of the Warrki Jarrinjaku ACRS project Pipirri Wiimaku 'for the little kids', Innovative Child Care Report, 2000 - 2001, senior Anangu and Yapa women identified four key principles underpinning all matters regarding the 'growing up' of their children (Waltja Tjutangku Palyapayi Aboriginal Organisation 2001):

(1) Tjukurpa (in Luritja and Pitjantjatjara) Jukurrpa (in Warlpiri): The Dreaming, the Law

(2) Waltja (in Luritja) Walytja (in Pitjantjatjara) Walartja (in Warlpiri): Family, extended family, all family

(3) Ngura (in Luritja and Pitjantjatjara) Ngurrara (in Warlpiri): The home, the land, the country, this place

(4) Kanyini (in Luritja and Pitjantjatjara) Mardarni (in Warlpiri): Holding everything, keeping everything together, Jukurrpa, Ngurrara and Walartja

The four principles describe the child's relationships and responsibilities between everything people, animals, land, family, Tjukurpa, Waltja, Ngura and Kanyini. Children are conceived and grow up with an understanding that they are part of this system and responsible for upholding these principles. In this article we attempt to provide an English interpretation for the key principles, although it is important to note that they can be conceptually challenging and difficult to define within a western cultural framework.

In the second major report produced as part of the Warrki Jarrinjaku ACRS project (Warrki Jarrinjaku ACRS Project Team 2002), the four principles are described in more detail. It is important to note that the senior Anangu and Yapa women working with Waltja come from a number of language groups in central Australia including Pintupi, Luritja, Warlpiri, Alyawarr, Kukatja and Arrernte. The common Aboriginal language for the group is Luritja and consequently the concepts Tjukurpa, Kanyini, Waltja and Ngura are usually referred to using the Luritja terms. In the following explanation the Warlpiri terms are included.

\section{Tjukurpa}

The following is a simple English definition for Tjukurpa (in Pitjantjatjara and Luritja) Jukurrpa (in Warlpiri):

Dreaming; the basis for Aboriginal Law and custom; the period during which the [Anangu and Yapa] social, moral and physical universe was created, which has on-going reality through the continuity of the practices that constitute the [Annangu and Yapa] cultures. (Vaarzon-Morel 1995, 111)

However, the concept of Tjukurpa needs to be used in its own right. A simple English translation is inadequate as there is no equivalent concept in the English language. Senior Anangu and Yapa women explain that Tjukurpa is similar, in some ways, to the concept of God. Tjukurpa is omnipotent and omnipresent and is based on the knowledge and activity that was established with ancestors and ancestral beings. Through art, songs, stories, ceremonies and everyday practice, 
Tjukurpa is passed from generation to generation. It explains and links land, animals, plants and people. It is implicit in all codes of behaviour, social organisation, and control and relationships between people, places and animals.

The rules for bringing up little children have been passed from generation to generation through Tjukurpa and a central focus of child rearing is the imparting of stories, rules and knowledge embedded in Tjukurpa. A baby becomes part of the Tjukurpa at conception.

Our grandparents showed us when we were children and we understand everything now because we were well educated. From the time that we were little children we learnt things, right up until we grew big and became old. It was as a child that I began to learn and carry it on [Jukurrpa, the Law] ... We are holding it, we are still looking after it [Mardarni (in Warlpiri); Kanyini (in Luritja, Pitjantjatjara)] ... Our understanding continues forever. We keep the Law eternally. (Molly Nungarrayi, translated from Warlpiri in Vaarzon-Morel 1995, 4)

\section{Waltja}

A simple English translation for the word Waltja (in Luritja), Waltyja (in Pitjantjatjara), Walarja (in Warlpiri) is 'family'. It does mean family but is much broader, referring not only to the nuclear family but also to a person's whole set of blood and marriage relations. Furthermore, the term Waltja is not strictly limited to those whom you are related to through blood or marriage. It also extends to include those with whom one is familiar, has stayed with, has been fed by and cared for, or grown up with. In a sense it can refer to anyone with whom a significant relationship has been shared, and includes people and animals.

Any known Aboriginal person can be included and addressed as though they were close family even if they have no actual blood relationship. Outsiders, even non-Aboriginal persons who come into a community, may be fitted into the Waltja system (Myers 1986). Waltja refers to a sense of belonging together or a shared identity. It also identifies the relationship between self and others, objects or places. The Pintupi and Pitjantjatjara categorise all people into family or non-family, waltja or mungutja (Myers 1986, 109).

\section{Ngura}

Ngura (in Luritja, Pitjantjatjara), Ngurrara (in Warlpiri) literally means: camp, home, place where people are staying or could stay; place, site; area or tract of country. The concept implies a sense of place; the place to which one belongs and the relationships and connections between people and place. Figures 7 and 8 provide two very different illustrations of Ngura.

\section{Kanyini}

Kanyini (in Luritja, Pitjantjatjara), Mardarni (in Warlpiri) literally means: having, holding, keeping; look after, mind, manage. Kanyini refers to the holding together of all connections, relationships, traditions, place, Dreaming and Law. It is the binding together and holding together of Waltja, Tjukurpa and Ngura (Pitjantjatjara and Warlpiri language dictionaries and personal commentary, Waltja Steering Committee). It is the concept that reminds people that it is vital to keep and maintain the rules, stories and ceremonies associated with your Tjukurpa, Waltja and Ngura. Wendy Nungarrayi Brown, in defining Mardarni, comments:

Mardarni means holding, keeping and watching everything - Tjukurpa, Waltja and Ngura. The big bosses [important Elders] tell us to hold and keep everything, tell us to follow Tjukurpa, know which Tjukurpa you belong to, what dance, what painting, ceremony, story, everything. Making sure you keep it, not lose it. (Wendy Nungarrayi Brown, personal commentary, 2006) 


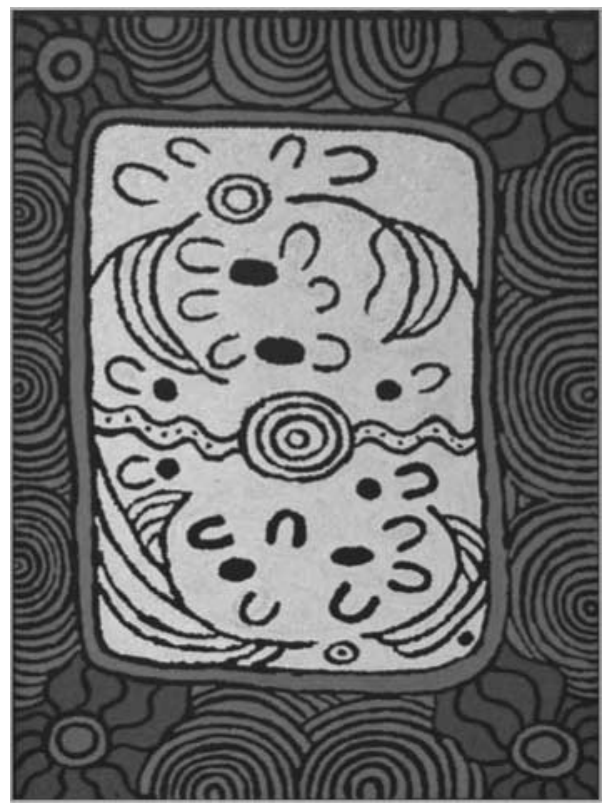

Figure 7. Painting by Irene Nangala of her country near Walungurru (Kintore), Northern Territory, Australia.

\section{Añangu and Yapa child-rearing practices}

One of the distinct features to emerge from the the Warrki Jarrinjaku ACRS work is the different perceptions Annangu and Yapa and Kardiya (non-Aboriginal people) hold in regard to babies and young children (Waltja Tjutangku Palyapayi Aboriginal Organisation 2001). In Kardiya (nonAboriginal) culture, babies are seen to be helpless and in need of a great deal of direction from adults, a perception that contrasts with the beliefs embedded in Anangu and Yapa child rearing. When Yapa and Anangu look at babies and young children they see small adults. These 'little people' have a set place in the family and the community, along with all the responsibilities of Law and culture. They may be addressed as 'my young auntie', 'my mother again' or 'my young grandfather' (Waltja Tjutangku Palyapayi Aboriginal Organisation 2001).

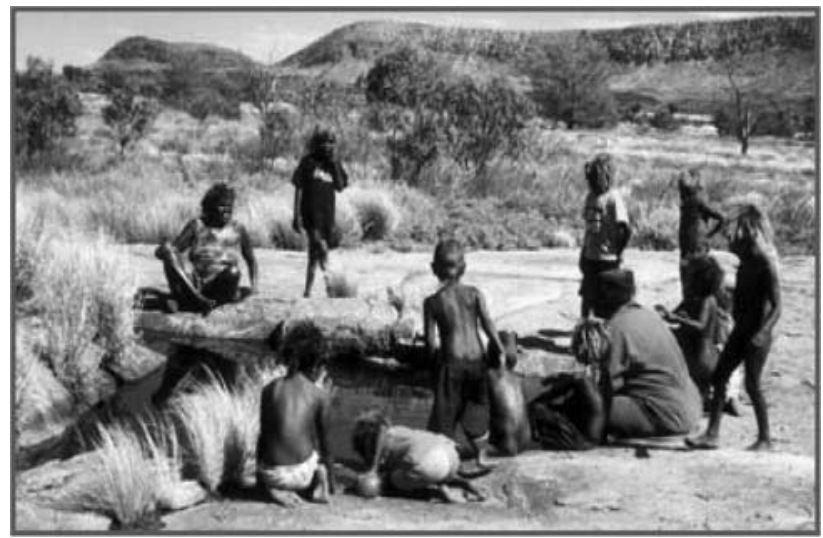

Figure 8. Photo taken near Walungurru (Kintore), Northern Territory, Australia. 
Young Yapa children are gradually introduced to their specific obligations and responsibilities associated with Jukurrpa. As part of these teachings young children have almost complete freedom to choose and demand whatever they desire. This is in contrast to Kardiya (non-Aboriginal) culture, where babies are required to develop routines as directed by adults (Jacobs 1988). Annangu and Yapa children sleep, eat and play whenever and wherever they choose. If babies cry they are immediately picked up and held; it is considered cruel to do otherwise. Furthermore, the Kardiya practice of putting babies and young children to sleep in a room on their own is considered inhumane. Yapa children never sleep on their own, and it is rarely a quiet environment for sleeping because they are always with their mother and other family members.

However, it is significant that the practice of responding to a child's wants as well as needs does not negate the existence of behaviour controls. Children are encouraged to behave in very specific ways. For example, an important feature of Anangu and Yapa child rearing is the emphasis placed on a child's ability to learn compassion for others and to share. Unselfishness and compassion are seen as highly desirable behaviours. Parents and family members demonstrate this by never denying children what they want. Generosity is seen as the natural way of behaving and consequently becomes so (Hamilton 1981). There is no concept of 'mine' in regard to a plaything. Children are actively encouraged to give away objects if another child desires them.

In learning about Tjukurpa, Waltja, Ngura and Kanyini, children learn the importance of relationships and the responsibilities they have to everything in their environment. They are taught to help and encourage one another, to keep each other safe and to work together. For example, nonAboriginal teachers in the classroom will often notice an older sibling completing a writing or drawing task for their younger relatives, particularly if the younger ones are having difficulty. According to Jukurrpa this is an older sibling's responsibility, as it is unacceptable to watch someone struggling when assistance is required. Individual merit has little value in such a learning environment.

\section{Growing together as leaders}

Anangu and Yapa socialisation of children focuses on the children being able to communicate appropriate understanding of their relationships to Tjukurpa, Waltja, Ngura and Kanyini. Kulini means to 'understand'. In understanding, a person acknowledges their relatedness to everything in the environment, and that they can subdue their own will in order to sustain relatedness (Myers 1986). As children grow and demonstrate that they are developing their understanding, they are gradually introduced to more knowledge. Learning continues throughout a person's life.

What the senior Anangu and Yapa women believe is happening now to their families is that people are forgetting their relatedness. They are not growing and understanding in the correct way - Kulini.

Of the four principles described in this article, Kanyini (in Luritja, Pitjantjatjara) or Mardarni (in Warlpiri) is the most difficult to maintain in contemporary times. Senior Annangu and Yapa women describe the difficulties they have in making sure their families follow Jukurrpa (the Law). Women continuously strive to keep their families together and healthy - to hold all connections, relationships, and traditions together. Petrol sniffing, substance misuse and the dependence on inappropriate systems weaken their communities - weaken Kanyini.

Warrki Jarrinjaku Jintangkamanu Purananjaku is the vision the senior women hold for their children and families - everyone working together as one and listening. The Warrki Jarrinjaku ACRS way of working happens when Anangu and Yapa (Aboriginal) and Kardiya (non-Aboriginal) people listen very carefully and respectfully to each other, and when they build the knowledge together. Warrki Jarrinjaku is about recording the correct way to grow up strong Yapa and Annangu children for today, and for future generations. This is so children and 
families will be able to learn and understand their relatedness to everything. They will know how to keep their culture strong and know their correct responsibilities.

\section{References}

Hamilton, A. 1981. Nature and nurture: Aboriginal child rearing in north-central Arnhem Land. Canberra: Australian Institute of Aboriginal Studies.

Jacobs, J. 1988. The construction of identity. In Past and present: The construction of Aboriginality, ed. J. Beckett, 31-44. Canberra: Aboriginal Studies Press.

Myers, F.R. 1986. Pintupi country, Pintupi self: Sentiment, place and politics among Western Desert Aborigines. Berkeley: University of California Press.

Priest, K. 2005. Preparing the ground for partnership: Exploring quality assurance for Aboriginal and Torres Strait Islander child care: A literature review and background paper. Canberra: FaCSIA.

Priest, K., S. King, W.N. Brown, and I. Nangala. 2003. Warrki Jarrinjaku: Working together everyone and listening: An innovative partnership between government and Indigenous communities in central Australia. Keynote address to Our Children the Future Conference, May, in Adelaide, Australia.

Taylor, R. 2003. An Indigenous perspective on evaluations in the inter-cultural context: How far can one throw a Moree boomerang? Evaluation Journal of Australasia 3, no. 2: 44-52.

Vaarzon-Morel, P., ed. 1995. Warlpiri women's voices: Our lives, our history. Stories collected by G Napangardi and J Nakamarra Long. Alice Springs: Institute of Aboriginal Development.

Waltja Tjutangku Palyapayi Aboriginal Organisation. 2001. Pipirri Wiimaku 'for the little kids' Innovative Child Care Report 2000-2001. Alice Springs: Waltja Tjutangku Palyapayi Aboriginal Organisation.

Waltja Tjutangku Palyapayi Aboriginal Organisation. 2005. Family news, 38: 4-5.

Waltja Tjutangku Palyapayi Aboriginal Organisation. 2006. Palya Palyanma Pipirri Wiima Tjutaku Child Care Resource Book 2000-2006. Alice Springs: Waltja Tjutaku Palyapayi Aboriginal Organisation.

Warrki Jarrinjaku ACRS Project Team. 2002. Warrki Jarrinjaku Jintangkamanu Purananjaku - working together everyone and listening: Aboriginal child rearing and associated literature. Canberra: Department of Family and Community Services.

\section{Disclaimer}

The Commonwealth of Australia accepts no responsibility for the accuracy or completeness of any material contained in the article. Additionally, the Commonwealth of Australia disclaims all liability to any person and in respect of anything, and of the consequences of anything, done or omitted to be done by any person in reliance, whether wholly or partially, upon any information presented in this review.

\section{Caution}

The views and recommendations of third parties, which are included in this review, do not necessarily reflect the views of the Commonwealth of Australia or indicate a commitment to a particular course of action.

Illustrations and photos in this article have been included with permission from Waltja Tjutangku Palyapayi Aboriginal Organisation.

Author: Kathryn Priest

Contributions from: Sharijn King, Wendy Nunguarryi Brown, Marilyn Nangala, Waltja Tjutangku Palyapayi Aboriginal Organisation. 